Andrzej Rzeczycki

University of Szczecin

e-mail: andrzej.rzeczycki@gmail.com

\title{
BAHAVIOURAL ASPECTS OF DECISION MAKING IN LOGISTICS
}

\begin{abstract}
Background: Managers goals may differ from the company's and the supply chain objectives. Theirs values and goals can lead to subjective-rational behaviours, which from the point of view of the organization will be irrational. Subrational behaviours may also result from motivational problems leading to the lack of commitment in new ventures, not taking opportunities, postponing tasks for later and transferring them to others. In addition should be added the issue of individual perception of the organization and its place in the supply chain. Perception of the supply chain results from the experience of cooperation with others and expectations for the future, and reflects the manager's knowledge about its environment. The image of the supply chain in which it operates may turn out to be residual. Empirical studies indicate the occurrence of multiple images of the supply chain in the same organization. The sensitivity of the image to the hierarchical position of the manager was identified, not only in the sense of the extent of perception with the position in the company, but also in the sense of imaging whole groups of people, not individual entities.
\end{abstract}

Methods: The study used critical analysis of the literature, followed by laboratory experiment combined with the methods of statistical analysis and simulation. Research was conducted by use of the assumptions of the game theory.

Results: On the basis of literature research concerning relationships occurring in supply chains and game theory, as well as experimental research carried out, the personality types of decision makers were standardized.

Conclusions: Standardizing the profiles of managers operating in the supply chain allows to more accurately predict their decisions, in other words, it is possible to operationalize their bahaviour.

Keywords: supply chain management, strategic decisions, bahavioural economics, game theory

A. Kolinski et al. (eds.), Contemporary challenges in supply chains, Vol. 1, https://doi.org/10.17270/B.M.978-83-66017-88-7.7 


\section{INTRODUCTION}

Management theory assumes that decision making is based on the rationality of action. The assumption of rationality is not so simple and transparent. In the broadly understood definition, decision-makers are considered as functioning rationally if and only if their behaviour can be interpreted as consistent with the rational choice paradigm. The assumption of this paradigm is that the individual decision maker has a precisely specified utility function (satisfaction from consumption or possession), whose arguments are defined as restrictions on potential choices. Therefore, rational behaviour consists in determining the set of amounts of resources that must be allocated for each of the possible applications as a solution to the problem of maximization with the existing restrictions [Hogarth R.M., Reder M.W., 1987]. In practical applications, a narrower definition of rationality is often used, associated with the maximization of expected utility [Sodryl M., 2009].

It is difficult to argue that decision-makers in reality always behave rationally, which is confirmed by allegations directed towards game theory (e.g. "gambler's error", which is a cognitive and logical error, consisting on treating independent random events as dependent events - in particular, this applies to thinking that an event that is an extension of some very unlikely series of events is less likely than an event terminating that series). In addition to the fact that sometimes (or even often) decision-makers do not have the ability to draw the right conclusions, they are also burdened with cognitive biases that systematically distort their view of the world. The criterion for the evolutionary selection of the brain isn't solving mathematical problems, but rather effective orientation in the world. Usually, involuntarily, strictness is sacrificed in favor of speed of reasoning, using various heuristics. There are also affective loads that do not always serve to maximize the expected utility [Ostasiewicz K., 2014]. Systematic studies on these cognitive loads were among the first to be started by A. Tversky and D. Kahneman [Tversky A., Kahneman D., 1974; Kahneman D., 2012]. J. Conlisk [1996] cites the results of psychological research and bahavioural experiments that confirm the existence of bahaviours contrary to the assumption of perfect rationality. People show intransitive preferences, misunderstand statistical dependencies, do not adapt their beliefs to the information obtained, confuse correlation with causality, use insignificant information, and omit relevant information, etc. Behavioral aspects in the context of supply chain operation are also undertaken by Slimani I., El Farissi I., Achchab S. [2015], who optimize logistics costs by modeling interaction between players in a single-channel, two-way supply chain. 
Apart from that, the driving force of human action is the human system of values and its needs. Thus, managerial goals may differ from those of the company and / or the supply chain. Values and goals dictated by them can lead to subjective and rational bahaviour, which from the organizational point of view will be irrational (or at least limited rationality will occur). Subrational bahaviour may also result from motivational problems leading to a lack of involvement in new ventures, failure to take opportunities, postponing tasks for later and transferring them to others. To this must be added the issue of individual perception of the organization and its place in the supply chain. The perception of the supply chain results from the experience of interacting with others and expectations about the future and reflects the manager's knowledge of his environment. The image of the supply chain in which it operates may turn out to be residual and short-sighted, or extensive and complex [Czakon W., 2017]. The image of the chain / network is a concept in which four dimensions have been identified [Corsaro D. et al., 2011, pp. 919-932]:

- power, expressed by the manager's perception of his dependence or independence from other actors,

- dynamics, expressed in time horizon and the number and frequency of episodic interactions between actors,

- extent, expressed in the variety and number of actors involved in the functioning of the chain,

- indirectness, which is related to the extent and expressed as the ratio of the number of indirect connections of a given manager to the number of his direct connections.

Disturbances in the rationality of the manager's actions may also result from less conscious causes. Among such deviations from rational bahaviour can be distinguished [Tyszka T., 2010; Zygan M., 2013]:

- aversion to lose - taking any action to defend against closing the position finished in minus,

- drowned costs effect - the tendency to stay with the decision, if it was associated with significant expenditure,

- the effect of ownership - assigning more value to things that can be lost than those that can be obtained,

- status quo effect - reluctance to change the existing state of affairs, 
- disposition effect - avoiding regret caused by loss, and striving for pride caused by profit,

- the effect of discounting financial gratuities - excessive evaluation of immediate profits,

- over-hedging - deposit of funds by people who should consume / invest them.

\section{EXPERIMENTAL RESEARCH ON DECISION-MAKERS' BAHAVIOUR}

A laboratory experiment was conducted to verify the assessment of the impact of bahavioural factors on decision making. Four games were carried out in the experiment, in which 132 people with knowledge and / or experience in the field of logistics operations took part:

1. "Dictator's game" - in which the participant shared the payment between himself and another person, and the variable factor was the level of knowledge of the person participating in the game. The goal was to verify the approach to rationality of action and the so-called purely economic bahaviour.

2. "Negotiation game" - the respondents were asked to indicate the amount of negotiated amounts depending on the changed factors, which included: amount of profit, level of risk, application of an ultimatum by the other party to the conflict. The goal of the game was to examine the rationality of the decision-makers' bahaviour.

3. "Make or buy game" - participants chose between creating their own good and buying from three suppliers depending on the profits from subsequent sales. The game was a kind of verifier of the participants' logic of thinking and the ability to indicate priorities for action, especially since in one of the rounds they could propose their own division (taking into account the indicated restrictions).

4. "Payment distribution game" - participants shared the costs of maintaining inventory in the supply chain in connection with the transfer of all inventory to one link. The goal of the game was to verify the sense of justice among the participants, as well as the logic of the proposed divisions.

The conducted experimental studies indicated disturbances in logic or rationality of human action as a decision maker. In the games conducted, it has been observed that the basis for making decisions can be creating your own image, social motives or bahavioural patterns encoded in human consciousness. On the other hand, wrong decisions may result from a lack of knowledge and skills, experience, information, or incorrect identification of the problem and 
unreflective actions. Often, "psychic-stitched" behaviours prompted study participants to make irrational decisions, especially in combination with other subliminal suggestions (e.g., the use of the word "split" suggested for most players a solution other than taking over the entire amount available). There has also been a number of fixations on the problem, without considering secondary issues that should affect the decision being made. An important observation was also that higher negotiation rates were associated with a greater risk appetite due to the unwillingness to lose potential income. In the case of the "make or buy" game, an interesting bahaviour was the choice of the purchase option, not because of the desire to focus on other aspects of the business (without losing profit), but also because of "giving earnings to the other players", and therefore not guided by economic rationality, but with some degree of altruism. Altruism, which was often not maintained in the case of a "pay-divide game", in which the understanding of fairness-sharing was tested. In this game vast majority of participants in the experiment chose the most favourable option from the point of view of one chain link, despite the more favourable option from the point of view of all links.

Based on the conducted research and literature analysis, four main groups of threats to the integrity and effectiveness of strategic actions resulting from making irrational decisions by a human were distinguished: personal, cognitive, motivational and informational (Fig. 1). 


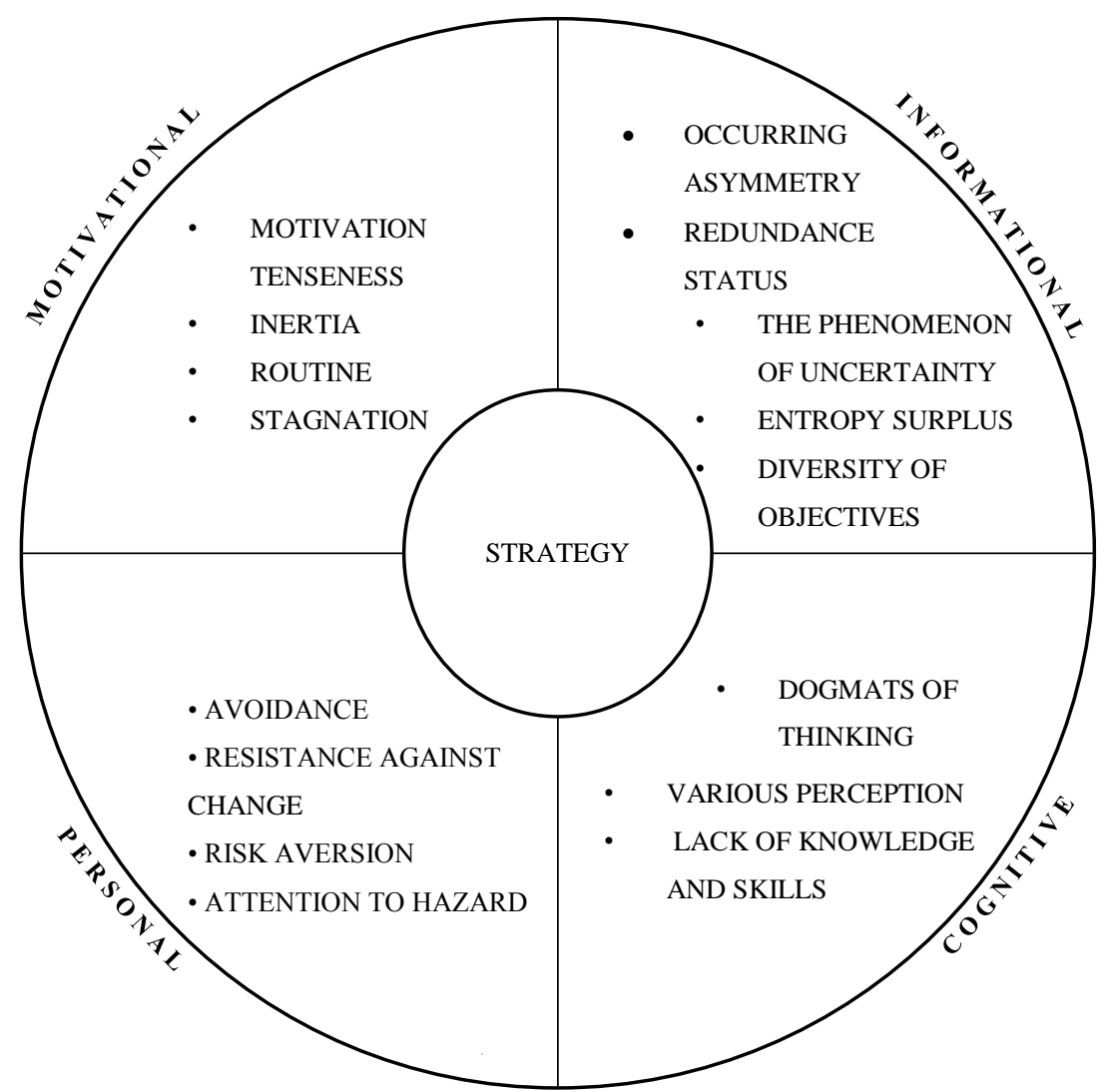

Fig. 1. Threats to the integrity and efficiency of strategic activities resulting from human decision making

Source: own elaboration.

STANDARDIZATION AND OPERATIONALIZATION OF MANAGER TYPES IN THE SUPPLY CHAIN AS AN ELEMENT OF IMPROVING THE OPERATION OF THE SUPPLY CHAIN

On the basis of literature studies on relations occurring in supply chains (mainly the KKK paradigm) and game theory, as well as experimental studies, the personality types of decisionmakers were standardized. The typology of highlighted players is presented in Figure 2.

A. Kolinski et al. (eds.), Contemporary challenges in supply chains, Vol. 1, https://doi.org/10.17270/B.M.978-83-66017-88-7.7 


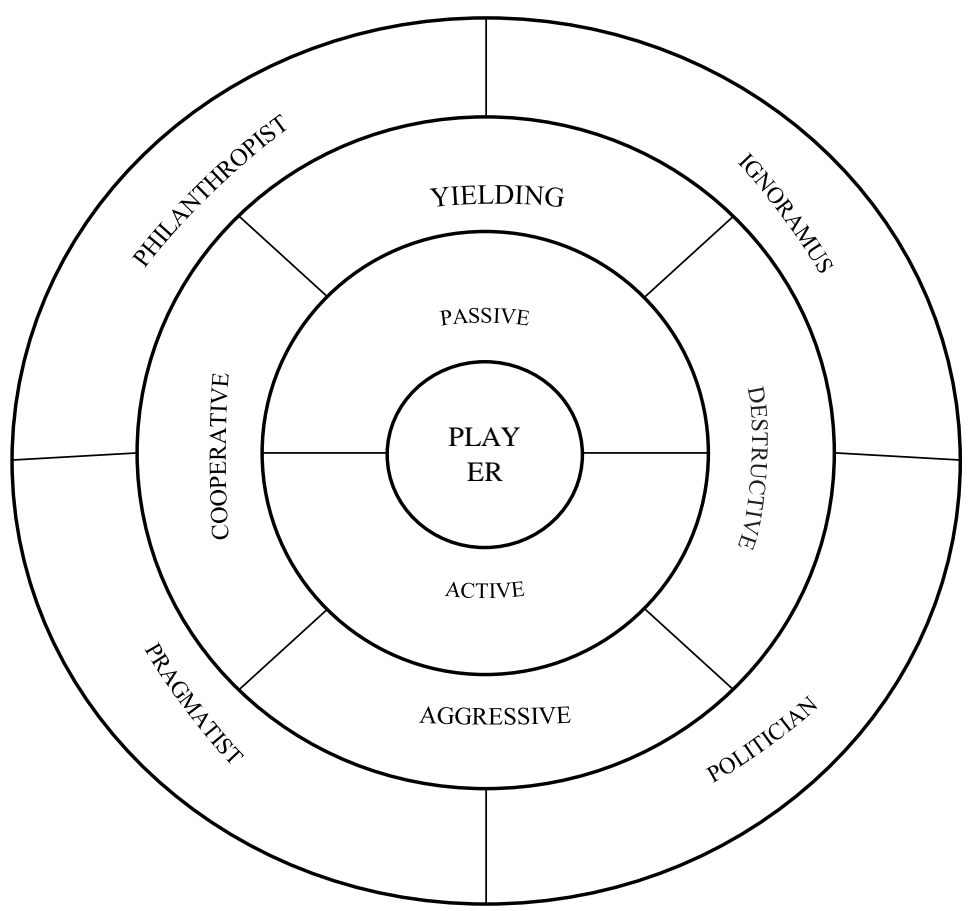

Figure 2. Players/ Supply chain managers personality types

Source: own elaboration.

Three levels of players / managers have been distinguished in the typology. The first, in general, refers to the classic approach to game theory and divides players into active and passive. The active player tries to look for strategic opportunities, so the manager who represents this style of game is a person open to new solutions, quickly makes decisions and initiates actions. He will also often take risks and take strategic moves in games, and his willingness to cooperate depends on the amount of potential benefit. The passive (conservative) agent will implement the minimum plan, i.e. the result above the assumed level will be satisfactory for him. The person representing this style is indecisive, so he quickly gives initiative and is under pressure. Unlike the active player, he is characterized by a low propensity for risk and the use of strategic moves, but he willingly joins in cooperation, especially formalized and long-term. Due to the minimalist goal, it is able to accept gaming solutions that are not optimal in the Pareto sense, and even outside the core of the game itself.

The second level of agent typology focuses on players in the context of relationships in supply chains. The aggressive player primarily represents the controlling and competing attitude, knows his position in the chain and will use it to achieve his goals. He is willing to use dominant strategies, works quickly and intuitively, and usually cooperates in the short-term 
(except for favourable contracts under which he can exercise control). The cooperating player, as the name suggests, is characterized by a high willingness to cooperate, and thus a high propensity to share information and maintain long-term formal and informal relations. In his actions he tries to be objective and conciliatory, he does not use threats, but only commitments and promises, he is able to take risks, but he does not do it too often and protects himself by spreading the risk among cooperating players. The concessive player is a decision maker controlled in the chain, willing to compromise and succumbing to suggestion, which is mainly due to low analytical skills. He usually has low bargaining abilities and the goal of his game is to achieve the assumed minimum score. For these reasons, he agrees to Pareto non-optimal results. The desire to avoid risk and solve problems by himself leads him to cooperate and establish long-term formal relationships. The last player at this level - destructive, is a product of negatively directed relations in the supply chain, mainly on a competitive basis. His goal is to maximize his own result and he is guided by the principle "the end justifies the means." $\mathrm{He}$ works impulsively and abuses the acquired economic power, so he relies rather on short-term contacts. He mainly uses threats, and his promises are unconfirmed, but he is able to use these tools even in informal relations. He is also characterized by a high risk appetite, and often also unreasonable bahaviour, therefore he is an unpredictable agent. Detailed characteristics of level one and two players are presented in Table 1.

The third level of players has been distinguished on the basis of experimental research and includes four personality types: pragmatics, philanthropist, politician and ignorant. A pragmatist is a logical thinker, conscientious and open to new opportunities, he seeks opportunities, controls emotions and manages risk effectively, but tries to avoid it whenever possible. Undertaking cooperation, its principles and the use of strategic moves in games depends on the profitability of such activities. The philanthropist is largely the counterpart of the cooperating player, but unlike him, he is characterized by a subjective approach, and sometimes even economically irrational bahaviour, which leads to agreement on non-optimal results in the Pareto sense. He establishes every kind of relationship, willingly shares information and avoids risky actions. Like the agent cooperating as part of strategic moves, he only uses commitments and promises. 
CONTEMPORARY CHALLENGES IN SUPPLY CHAINS VOL. 1

Table 1. Characteristics of distinguished types of players of the first and second level

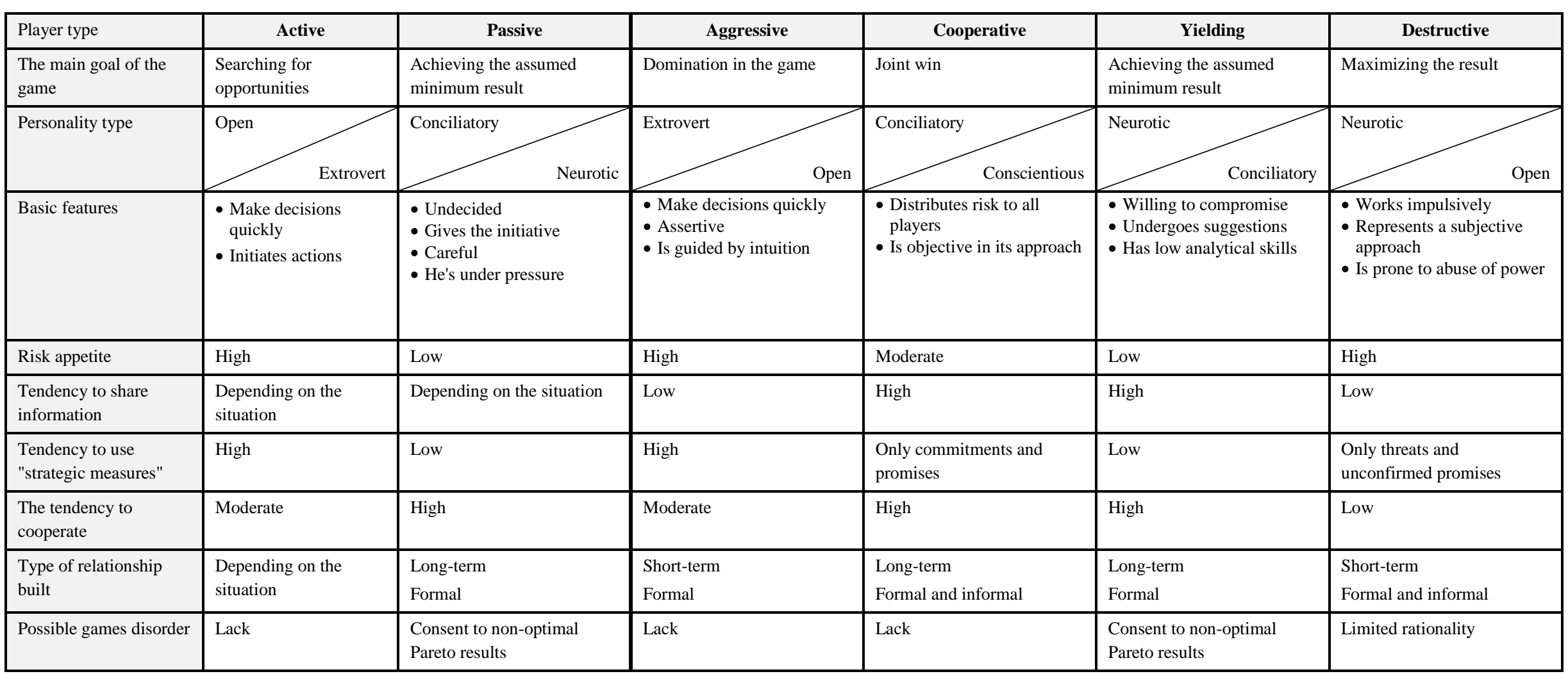

Source: own elaboration. 
A politician (idealist, individualist) is a player focused on achieving individual goals. Although ambitious and assertive, open to new opportunities, it belongs to people with a neurotic disposition. It is characterized by a moderate tendency to cooperate and share information, and a high propensity to use strategic moves and bluff. These features make him an unpredictable player. The last highlighted type is ignorant, whose goal is usually to achieve the assumed minimum goal. The basic features of a person described as ignorant are low analytical skills, lack of knowledge and experience in running a business, which results in escaping from risk, relying on others, succumbing to their suggestions and, as a consequence, establishing cooperation. Lack of experience means that he rather does not use strategic moves, but also less often shares information (although he does so not because of knowledge of their value but ignorance of the effects of such bahaviour). The detailed characteristics of level three players are presented in Table 2.

Table 2. Characteristics of the distinguished types of level three players

\begin{tabular}{|c|c|c|c|c|}
\hline Player type & Pragmatist & Philanthropist & Politician & Ignoramus \\
\hline The main goal of the game & $\begin{array}{l}\text { Searching for } \\
\text { opportunities }\end{array}$ & Joint win & $\begin{array}{l}\text { Achieving individual } \\
\text { goals }\end{array}$ & $\begin{array}{l}\text { Minimum result } \\
\text { assumed }\end{array}$ \\
\hline Personality type & Conscientious & Conciliatory & Open & Neurotic \\
\hline Basic features & $\begin{array}{l}\text { - Thinking logically } \\
\text { - Controls emotions } \\
\text { - Effectively manages } \\
\text { risk }\end{array}$ & $\begin{array}{l}\text { - Empathic } \\
\text { - Represents a } \\
\text { subjective approach } \\
\text { - Solves problems } \\
\text { easily but avoids } \\
\text { them }\end{array}$ & $\begin{array}{l}\text { - Ambitious } \\
\text { - Assertive } \\
\text { - Is guided by intuition } \\
\text { - Represents a } \\
\text { subjective approach }\end{array}$ & $\begin{array}{l}\text { - Willing to } \\
\text { compromise } \\
\text { - Undergoes } \\
\text { suggestions } \\
\text { - Has low analytical } \\
\text { skills }\end{array}$ \\
\hline Risk appetite & Moderate & Low & High & Low \\
\hline $\begin{array}{l}\text { Tendency to share } \\
\text { information }\end{array}$ & $\begin{array}{l}\text { Depending on the } \\
\text { situation }\end{array}$ & High & Moderate & Moderate \\
\hline $\begin{array}{l}\text { Tendency to use "strategic } \\
\text { measures" }\end{array}$ & Moderate & $\begin{array}{l}\text { Only commitments and } \\
\text { promises }\end{array}$ & High & Low \\
\hline The tendency to cooperate & Moderate & High & Moderate & High \\
\hline Type of relationship built & $\begin{array}{l}\text { Depending on the } \\
\text { situation }\end{array}$ & $\begin{array}{l}\text { Short- and long-term } \\
\text { Formal and informal }\end{array}$ & $\begin{array}{l}\text { Depending on the } \\
\text { situation }\end{array}$ & $\begin{array}{l}\text { Long-term } \\
\text { Formal }\end{array}$ \\
\hline Possible games disorder & Lack & $\begin{array}{l}\text { Consent to non-optimal } \\
\text { Pareto results }\end{array}$ & Limited rationality & Limited rationality \\
\hline
\end{tabular}

Source: own elaboration.

The presented types of players can connect with each other, but only on the basis of their neighborhood - according to Figure 2, e.g. you can talk about a pragmatic philanthropist and a pragmatic politician, but there isn't pragmatic ignorant. The same principle of joining occurs 
between levels, i.e., for example, you can talk about cooperative philanthropist (enhancing traits) or yielding philanthropist (extortion of bahaviour).

\section{CONCLUSIVE REMARKS}

Rationalization can be achieved both at the internal level of the organization (logistic aspects of business strategy, functional strategy) and external (supply chain strategy). There are, however, some differences in the approach to games. At the internal level, games are less complicated because they usually involve fewer players, and activities are subordinated to the overall strategic concept. The external level is regulated by relationships of various nature, and the heterogeneous goals of chain participants and the way the managers perceive the chain increase the number of likely interactions.

Assigning the appropriate decision-making scope (games) to the manager (player) allows to maximize (rationalize) the results of these decisions, e.g. the "pragmatist" player has better predispositions to design cost strategies, and the "policy" player prefers a pro-quality approach due to lower ability to search for sources of cost reductions. The player can also influence the game environment by modifying it e.g. in terms of time. Accelerating the cycle can create a new value, disrupting the opponent's actions. Thus, due to the significant impact of the player type on the decisions made and results achieved, an extremely important issue is the further identification of personality types, their standardization and operationalization in games and business.

\section{REFERENCES}

Conlisk J., 1996, Why Bounded Rationality?, Journal of Economic Literature, 34, 669-700.

Corsaro D., Ramos C., Henneberg S.C., Naude P., 2011, Actor network pictures and networking activities in business networks: An experimental study, Industrial Marketing Management, 40(6), 919-932, DOI: 10.1016/j.indmarman.2011.06.028.

Czakon W., 2017, Obrazy sieci w zarządzaniu strategicznym, Zeszyty Naukowe Wydziału Zamiejscowego w Chorzowie Wyższej Szkoły Bankowej w Poznaniu, 19, 71-81.

Hogarth R.M., Reder M.W., 1987, Rational choice: The contrast between economics and psychology, Chicago, IL, US, University of Chicago Press.

Kahneman D., 2012, Pułapki myślenia. O myśleniu szybkim i wolnym, Media Rodzina, Poznań. 
Ostasiewicz K., 2014, Racjonalność, konflikty i teoria gier w życiu i pracy Roberta J. Aumanna (Nagroda Imienia Nobla w Dziedzinie Ekonomii, 2005), Śląski Przegląd Statystyczny, 12(18), 285-312, DOI: 10.15611/sps.2014.12.16.

Slimani I., El Farissi I., Achchab S., 2015, Application of game theory and neural network to study the behavioural probabilities in supply chain, Journal of Theoretical and Applied Information Technology, 82, 3, 411-416.

Sodryl M., 2009, Założenie racjonalności w ekonomii neoklasycznej, [in:] Funkcjonowanie gospodarki polskiej po 20 latach transformacji, Kopycińska D. (red.), Wydawnictwo Uniwersytetu Szczecińskiego, Szczecin, 7-18.

Tversky A., Kahneman D., 1974, Judgement under Uncertainty: Heuristics and Biases, Science, 185, 1124-1131, DOI: 10.1126/science.185.4157.1124.

Tyszka T., 2010, Decyzje - perspektywa psychologiczna i ekonomiczna, Scholar, Warszawa. Zygan M., 2013, Ekonomia behawioralna - wprowadzenie do problematyki, Zeszyty Naukowe Uniwersytetu Szczecińskiego. Studia i Prace Wydziału Nauk Ekonomicznych i Zarządzania - Problemy współczesnej ekonomii, 32, 2, 9-22. 